\title{
WILLINGNESS TO COMMUNICATE AND ITS INFLUENCING FACTORS AMONG INDONESIAN PRE-SERVICE TEACHERS
}

\author{
${ }^{1}$ Indry Widyasti Anwar, ${ }^{2}$ Min Jung Jee, ${ }^{3}$ Sutisno Adam, \& ${ }^{4}$ Sartika Sailuddin \\ ${ }^{1}$ Faculty of Teachers Training and Education, Khairun University, Indonesia \\ ${ }^{2}$ Faculty of Humanities and Social Sciences, The University of Queensland, Australia \\ ${ }^{3}$ Faculty of Cultural Sciences, Khairun University, Indonesia \\ ${ }^{4}$ Faculty of Education, Muhammadiyah University of North Maluku, Indonesia \\ Corresponding Author Email: indrywidyasti@yahoo.com
}

\begin{tabular}{ll}
\hline \hline Article Info & Abstract \\
\hline Article History & Willingness to communicate (WTC) can be defined as the readiness of a language \\
Received: September 2021 & learner to enter a communication situation. This study aims to identify factors \\
Revised: September 2021 & $\begin{array}{l}\text { affecting pre-service teachers' WTC and to explore their perspective on the } \\
\text { Published: October } 2021\end{array}$ importance of WTC in relation to the study program. The study implemented both \\
Keywords & quantitative and qualitative methods to gain a deeper understanding from \\
Willingness to & questionnaires and interview data. Questionnaires were used to explain the \\
communicate; & interrelated relationship between variables affecting WTC among pre-service \\
language anxiety; & teachers. Interview data were used to report their perspective on the significance \\
Motivation; & of WTC in relation to their study program. The result inferred that pre-service \\
Learners'beliefs; & teachers have relatively high WTC. The motivation variable scale indicated \\
& direct positive relation to pre-service teachers WTC, while anxiety showed a \\
& negative relationship. Language learning beliefs items were reported to be \\
& moderately agreed upon among pre-service teachers influencing their WTC. The \\
& interview result inferred that pre-service teachers mostly agreed upon the \\
& significance of enhancing WTC among learners. Implications for learning as a \\
& result of this study suggested that teachers and curriculum makers improve \\
& teaching techniques and approaches in order to enhance learners' WTC.
\end{tabular}

How to cite: Anwar, I. W., Jee, M. J., Adam, S., \& Sailuddin, S. (2021). Willingness to Communicate and Its Influencing Factors among Indonesian Pre-Service Teachers. JOLLT Journal of Languages and Language Teaching 9(4), pp. 385-398. DOI: https://doi.org/10.33394/jollt.v\%vi\%i.4201

\section{INTRODUCTION}

This study took place in the Indonesian classroom context, involving students of English teacher-study programs. Participating in the study are students of pre-service teachers in their final year of study. Pre-service teachers in the English study program are being prepared to perform English teaching at some selected schools as one of the requirements to graduate. It is required for teachers to be proficient in communication so that they can make sure students get the best classroom experience through a comprehensive learning activity. Furthermore, students are especially emphasized to be able to produce authentic communication as part of language learning and instruction. Therefore, WTC is treated as one of the key concepts in language learning and instruction (Kang, 2005). Thus, pre-service teachers are trained to be proficient in communication skills in order to prepare themselves to enter a real teaching context in the future.

The aim of the study is to examine factors underlying pre-service teachers' WTC in English study program by looking into the relation of factors such as anxiety, motivation, and language learners' beliefs to their level of WTC. Bernat and Gvozdenko (2005) stated that beliefs potentially affect students' attitudes about language learning, motivation and contribute to how students are shaping their experiences and actions in the learning process. Through this research, we will see how beliefs around language learning can affect students' 
WTC. Finally, pre-service teachers in this study describe their perspective on why WTC is significant among teachers in relation to their study program. The result from this research is expected to provide insights for Indonesian EFL teachers regarding factors that influence learners' WTC in-classroom seminars.

First proposed in the 1990s by McCroskey and colleagues (McCroskey \& Baer, 1985; McCroskey \& Richmond, 1987, 1990, 1991), the concept of WTC has unveiled significant factors which lie on between an individual's actual communication competence and the intention to communicate. In the classroom, it can be observed that some students like to talk while other students prefer to avoid speaking or only when spoken to. The layers between one's communication competence and the actual communication practice are affected by an individual's psychology, linguistics, and contextual variables (McCroskey \& Richmond, 1987, 1990, 1991). The construct of WTC is presumed to be trait-like personality-based, as people maintain to keep on the regularity of their WTC across situations. However, WTC can also be specific situational variables. Although one's may carry a specific trait-determined level of WTC, various behavior of WTC can be portrayed across situations (McCroskey \& Richmond, 1990). On another examination of WTC in L1 context, MacIntyre discovered that communication apprehension and perceived communication competence are two factors affecting WTC (MacIntyre, 1994). In a further study (MacIntyre, Babin, and Clement, 1999), WTC in L1 context can encompass both individual traits and states.

Many studies of WTC have also tried to seek the interrelationship between learners' beliefs and WTC (Peng \& Woodrow, 2010; Peng, 2012). Beliefs on language learning affect motivation and communication anxiety, which in turn affects students' WTC (Peng \& Woodrow, 2010). Students who believe that interrupting teachers with a question in the classroom is an unpolite behavior might avoid participating actively, which reduces their WTC. Horwitz (1988) invented the Beliefs About Language Learning Inventory (BALLI) in major areas of language learning, such as the difficulty of language learning, foreign language aptitude, the nature of language learning, learning and communication strategies and motivations and expectations. BALLI instrument has been widely used in many research exploring beliefs on language learning in many countries such as Lebanon (Diab, 2006), Taiwan (Yang, 1999), the United States (Oh, 1996), and Turkey (Ariogul \& Onursal, 2009). The results have discovered several common beliefs patterns of language learners within the concept of language aptitude, the hierarchy of language difficulty, and the importance of learning vocabularies. Wong (2010) in an investigation of WTC in the Malaysian EFL context, found that Malaysian pre-service teachers mostly believe children are better language learners than adults and that some people are gifted with the skills to learn the language better than others.

Within the Indonesian context, a recent study exploring learners' perspectives of their WTC indicated that social and classroom context, linguistic competence, individual differences, and cultural context influence learners' WTC in L2 (Fadilah, 2018). Another research investigating Indonesian EFL learners' Instructional WTC addressed that gender, group size, classroom environment, students' cohesiveness, topic familiarity, degree of topic preparation, classroom seating, self-awareness, and familiarity with interlocutors influence learners' WTC (Amalia, Asib \& Marmanto, 2019). In a classroom situation, it is the duty of teachers to monitor learners' participation and to provide reinforcement in order to stimulate their classroom engagement. Prasetyanto et al. (2019) reported that teacher reinforcement in the EFL classroom could help influence learners' WTC through affective factors of selfconfidence, interpersonal motivation, and intergroup motivation.

A study among pre-service teachers in Malaysia (Yousef, Jamil, and Razak, 2013) indicated a significant correlation between Language learning communication strategies and WTC through motivation and self-perceived communication competence. Another study of 
WTC among trainee teachers in Malaysia (Fahim and Dhamotharan, 2016) inferred that male students are more willing to communicate in English compared to female students. No significant differences were found on the influence of nationality to WTC but a significant difference was seen among ethnic groups where Indian students performed the highest WTC with friends compared to Chinese and Malay students. Course choice also affected WTC in a significant result and no significant difference in terms of year of the study spent in the program to their WTC.

Among the few pieces of research of WTC involving students of pre-service teachers, there was no research that attempted to investigate students' perspectives on the importance of WTC in relation to their study program as English teachers. Therefore, this study is trying to fill in the gap to look into factors affecting pre-service teachers' WTC in classroom activity and perspective on the significance for pre-service teachers to have high WTC to support their future teaching career. From the research, it is expected to gain an understanding on factors influencing WTC among pre-service teachers in order to prepare them to construct effective teaching approaches for the need to enhance learners' WTC. Therefore, two research questions are addressed. The first research question is to identify how factors such as language anxiety, motivational intensity, and beliefs on language learning related to preservice teachers' WTC in the Indonesian context. The second research question is to see the pre-service teachers' perceptions regarding the significance of WTC in relation to their study program.

\section{RESEARCH METHOD \\ Research Design}

Collected data were analyzed in quantitative and qualitative methods. The implementation of mixed method is done to achieve a fuller comprehension of a particular phenomenon and to verify a set of findings (Sandelowski, 2003 in Dornyei, 2007). The questionnaire was used to explore factors influencing pre-service teachers' WTC. Several measures identifying factors loading WTC in the questionnaire were adapted from a previous study in Peng \& Woodrow (2010). The questionnaire will look into four aspects; WTC in English, communication anxiety in English, motivation to learn English and language learning beliefs. The result from the questionnaire will be used to seek correlations between WTC in English to language anxiety and motivation. At the same time, the result from the language learning beliefs scale will be described in a separate section. The questionnaires have forty-five items in total and are scored on Scale 1 (strongly disagree) to 5 (strongly agree).

The researcher conducted a semi-structured interview in order to describe students' perception on the significance of WTC in relation to their study program as pre-service teachers. Ten students voluntarily signed up for the interview. For participant convenience, they can choose to do the interview in Indonesian language or English. Participants were asked to describe the importance of WTC in terms of taking an active role in classroom oral participation. Participants were asked to reflect on the significance of WTC in relation to the study program they are currently enrolled in.

\section{Participants}

The study was conducted in a state university in North Maluku, Indonesia. Participants are students enrolled in the Faculty of Teachers Training and Education Program, majoring in the English Department. Participants are students in their fourth or fifth year of undergraduate study. Participating in the survey questionnaires are 34 students, consisting of 22 females and 12 males ranging from 20-25 years. Students chosen are in the final academic year because they are more prepared for field teaching practice at some selected schools, which is a compulsory requirement to graduate. By involving students in their fourth year, it is expected 
to obtain a clearer understanding of willingness to communicate from the pre-service teacher students because at this level of study. They are able to explain better the significance of their program choice into their willingness to communicate.

\section{Instruments}

Questionnaires were used to measure factors that are affecting students' WTC using three measurements adopted from the previous study in Peng \& Woodrow (2010). The questionnaire consists of four scales, measuring WTC in English, communication anxiety in English, motivation to learn English, and language learning beliefs. Each scale was rated on a 5-point Likert scale ranging from 1 (strongly disagree) to 5 (strongly agree), implying the higher the score, the higher to the level of each scale. Each of the scales are described as follows;

i. WTC in English scale measuring WTC in speaking consist of ten items, and the Cornbach's alpha was .81 in a pilot study.

ii. Communication anxiety in English scale is presented on a 5-point scale consists of twelve items $(\alpha=.90)$.

iii. Motivational intensity in learning English scale consist of eleven items to measure extrinsic and intrinsic motivation in a 5-point Likert scale $(\alpha=.83)$.

iv. Learners beliefs scale is designed as a 5-point Likert scale consisting of twelve items $(\alpha=$ .66)

An interview is designed to explore students' perspectives regarding the significance of WTC in relation to their study program of teacher training. During the interview, students will be asked to describe the significance of WTC especially as pre-service teachers

\section{Data Analysis}

Questionnaire data were analyzed using the Statistical Package for the Social Sciences (SPSS). The use of SPSS aims to see the interrelated relationship between variables (WTC in English, communication anxiety, motivational intensity) affecting students' WTC in English as well as descriptive data of each variable. After transcribing and translating interview data using standard orthography, content analysis was used to explain the data obtained during interviews in order to analyze theme through coding and interpreting textual material. The purpose of content analysis is to identify important aspects of the data content clearly and effectively in order to support some argument that will contribute to the field.

\section{RESEARCH FINDINGS AND DISCUSSION Research Findings}

1. Questionnaires

Table 1 shows the descriptive statistics from the result of measuring pre-service teachers' WTC in English, communication anxiety and motivation.

Table 1

Descriptive Statistics of the Variables

\begin{tabular}{lll}
\hline Variables & M & SD \\
\hline WTC & 4.03 & .537 \\
Communication anxiety & 2.70 & .723 \\
Motivational intensity & 4.36 & .412 \\
\hline
\end{tabular}

The result inferred that participants showed high WTC in English $(M=4.03, \mathrm{SD}=$ 0.53). Participants showed moderately low anxiety in terms of English communication in classroom $(M=2.7, \mathrm{SD}=0.72)$ while motivational intensity in language classroom are fairly 
high $(M=4.36, \mathrm{SD}=0.41)$. Data were tested using Pearson correlation to find relationship between the three scales affecting WTC on students of the teachers study program. The result is shown as follow;

Table. 2

\begin{tabular}{llll}
\multicolumn{3}{c}{ Correlations of WTC and the Variables } \\
\hline \multirow{4}{*}{ WTC } & Communication & $\begin{array}{l}\text { Motivational } \\
\text { Intensity }\end{array}$ \\
\cline { 2 - 4 } & & Anxiety & $.792^{* *}$ \\
& Pearson Correlation & -.286 & .000 \\
& Sig. (2-tailed) & .101 & 34 \\
\hline
\end{tabular}

**. Correlation is significant at the 0.01 level (2-tailed).

*. Correlation is significant at the 0.05 level (2-tailed).

The result indicated a negative and statistically no relationship between communication anxiety and WTC in English $(r=-.286)$. Considering that the participants are students in their last year of study might explain why they have low anxiety levels. Typically, students in their final year are more experienced in classroom learning which explains the low anxiety level. Meanwhile, a significant correlation between students' WTC in English and motivational intensity was found $(r=.792)$. A variety of internal and external motivations of each learner can contribute a big effect to their WTC. High motivational intensity might also explain why participants show moderately low anxiety in English communication.

Questionnaires on students' beliefs about language learning showed moderately neutral agreement on several language learning beliefs $(M=3.34, S D=0.30)$. Pre-service teachers mostly believe that mistakes during English communication is fine as long as each speaker understands each other. Pre-service teachers mostly agreed on the importance of learning grammar rules in language learning. They also perceive that learning English is about translating it into the Indonesian language. Pre-service teachers showed low agreement on the accuracy of pronunciation while speaking. They also perceive that the students who always speak up in class do not mean to be showing off. Table 3 shows the mean scores of each item on beliefs on language learning.

Table 3

Descriptive Statistics of Learners' Beliefs

\begin{tabular}{llll}
\hline Beliefs Item & M & SD \\
\hline 1. The student who always speaks up in class will be loathed by other & 2.76 & 1.20 \\
classmates. & & 1.16 \\
2. The student who always speaks up in class is showing off his/her English & 2.70 & .95 \\
proficiency. & 3.41 & 1.00 \\
3. Students can speak up in class even without being invited by the teacher. & 2.88 & 1.10 \\
4. I learn more by participating in communication activities in class. & 3.26 & 1.08 \\
5. Learning English is mostly a matter of translating from Indonesian. & 3.50 & .71 \\
6. To understand English, it must be translated into Indonesian. & .95 \\
7. Making error in oral English speaking fine as long as people can & 4.08 & .99 \\
8. The most important part of learning English is learning grammar rules. & 3.58 & \\
9. In English classes, I prefer to have my teacher provide explanations in & 2.97 & & 1.07 \\
Indonesian. & 3.44 & 1.14 \\
10. You can raise an opinion even if you are not sure it is correct. & & \\
11. You can say something in English even though you can not speak it & 3.79 & \\
correctly. & 2.35 & 1.06 \\
12. Speaking English should be done with excellent pronunciation &
\end{tabular}




\section{Interview Analysis}

Based on the students' responses, four major themes were identified: Affecting factors of WTC in classroom, Teachers' influence on WTC, Teaching and learning strategy, and The significance of WTC in relation to study program.

\section{Affective factors}

\section{Perceived communication competence}

Perceived communication competence has been viewed as one factor influencing WTC as research in the field of reticence (Phillips, 1968,1977, 1984) showed that the lack of communication skills can reduce one's willingness to communicate. The choice to communicate is a cognitive option, it is likely to be influenced by the perceptions of competence rather than the actual competence (McCroskey \& Richmond, 1991). During the interview when asked to rate their own WTC in English classroom, six participants perceived themselves to be confidence in speaking and are willing to speak in classroom when there are chances to interact.

"when the lecturer or the teacher use English, I will respond them in English too. And so on if my friends use English, I will use English too. I think I have pretty good English. But I rarely used English outside of the class. "(respondent 2)

Self-perceived communication competence combined with anxiety creates one's selfconfidence. When learners show lower anxiety and a high level of perceived communication competence, they tend to take possible chances in communication with a certain person or group (Yashima, 2002).

\section{Anxiety}

Learners often times encountered the anxiousness in classroom which is closely related to self-confidence. Language anxiety may come from the feeling of inability to do a certain task in language classroom which affects learners' self-perceived communication competence thus, influences their WTC (Maclntyre, Noels, and Clement,1997).

"some of my friends are having low confidence so they don't really try to speak with friends or with me, maybe they are just doing their communication or speaking is just like only if there is a assignment or task from the teacher, presentation or any discussion." (respondent 4)

Some pre-service teachers explained that the existence of anxiety in classroom interaction is caused by a lack of confidence. They tend to speak only when a speakingrelated task is required. Horwitz, Horwitz, and Cope (1986) categorized this type of anxiety as a communication apprehension which is characterized by the feeling of shyness or fear to talk to someone. Another source of anxiety is the fear of making mistakes in the classroom to avoid getting negative evaluations.

\section{Motivation}

Most pre-service teachers talked about extrinsic motivation. For instance, the motivation to speak and interact in an English classroom comes from the awareness of their responsibilities as language learners and future teachers. Learners are also motivated by their internal goal of studying abroad as a result of being proficient in English. Yashima (2002) argued that learners who are motivated to learn English in order to try to achieve their goals tend to have higher trust in their own ability in English communication. 
"I am motivated because I as teacher to be so what I know I must to be brave to speak up in the class because umm I am teacher to be, so in classroom the teacher as a control or educator they have to be, they have to speak up in the class because they will teach their students so this is the turning for us how we can train ourselves to be the best teacher in the classroom." (respondent 3)

\section{English proficiency}

Many students reported feeling less proficient in English specifically on grammar. Lack of language proficiency will lead to the feeling of inferiority toward other peers. In the EFL context, it is very common to find learners cramming on grammar matters. Yashima (2002) revealed a significant relationship between variables of WTC and students' proficiency in terms of grammar. Similar to Imran and Ghani (2014), their participants who had higher results in grammar proficiency tests were more willing to communicate than others who were reluctant to participate in classroom interaction where they tend to have lower proficiency in grammar.

"maybe they are scared to the mistake so the mental block is the main thing in their mind that they will do the mistake so they afraid to other students who are having the good ability than them." (respondent 7)

\section{Classroom environment}

During the interview, three students reported on classroom situations which can influence WTC. Several aspects involving classroom atmospheres such as mood, emotions, or climate that are felt and shared by the class members. Pre-service teachers are affected by their peers. When there is no one showing active participation in the classroom, others will also remain silent. Meanwhile, when the classroom flow becomes more interesting, others will be thrilled to speak up. From an ecological perspective, learners are part of classroom members that are embedded in the environment. If there are any changes in one's behavior during classroom learning, it will influence the atmosphere in the classroom environment (Peng, 2012).

“....so most students especially in my class maybe they don't have something like braveness and encouragement in English. Uumm maybe they are not interested. So the class become boring and nobody want to speak at all. But if the class become interesting, some students start to speak and others will join.” (respondent 5).

Teachers influence on WTC

Teachers' English proficiency

Teachers were also identified as one of the motivational factors in WTC during the interview. Teachers who possess an excellent English speaking ability can boost learners' interest. When teachers perform sufficient English speaking ability, the students will be motivated to copy their teacher and try communicating in English.

"it is important because when teacher can show it to the students then they will have a role model there. The teacher themselves already show us how to speak in that language and it sound fine when she or he speaks, we will be motivated to speak also." (respondent 1)

Students enjoy learning with teachers who are open, good at speaking English and perform various communicative classroom activities. On the other hand, teachers can also be the source of discouragement. Some students reported being bored and demotivated when 
teachers ignore using English in a language classroom. Creating a rich English environment in classroom interaction is important so that students can copy the use of the language and familiarize themselves with the language features.

"most teachers especially for my class, maybe on the first introduction before they are going to teach us they will use English but at the middle of the lecture maybe they just use bilingual sometimes English sometimes Indonesian" (respondent 5)

\section{Teachers' teaching style and approach}

Approaches and strategies of teaching in language classrooms were also reported as factors affecting learners' WTC. Pre-service teachers expressed their interest toward teachers who actively seek opportunities to create an insightful learning situation, such as asking questions, doing games or small quizzes, and giving feedback. Exciting and creative approaches in teaching result in complete involvement between learners and teacher interaction in classroom communication. Teachers' factors were found to be significantly affecting learners' WTC in Peng's (2012) WTC investigation. Therefore, teachers are suggested to provide effective support for learners during learning by showing empathy and encouragement.

"Let's say one teacher is just explaining the grammar or vocabulary and just simply ask students to make sentences in written form. But other teacher tries to push them actively like giving them chances to express what they are thinking toward this material or what are their opinions toward this kind of rules, or even tries to give the students chances of how they understand certain material for example. That will encourage them more in understanding the material in their own way and also how to explain this in their target language." (respondent 1)

However, teachers need to be aware not to make students feel like being the center of attention. One student described that being suddenly asked a question and being forced to answer in English makes them embarrassed. Threatening students' positive face seems to be a common practice in some parts of Indonesian classroom whenever the teachers want to see more interaction in the classroom. As a result, students will feel threatened, lose motivation and concentration.

"and also they sometimes make the students shy by..by pushing them to speak so they, "if I ask you in English you have to answer me in English....... they just force the students to speak but they can be scared." (respondent 5)

\section{Teachers' authority}

The use of authority by teachers in classroom sometimes hapened in a way that might discourage the students. One student mentioned that there are some old-styled teachers who perceive themselves to be the only one the students should listen. This type of teacher rarely listen to the opinions from students because they perceive themselves to have the highest authority in classroom. Students are sometimes treated as they know nothing more than the teachers' state of knowledge and so students should not question their teachers' statement.

"when the teachers give material and students have something to add, teachers should accept it. Because what teachers know and what students know maybe not the same. So if students want to ask something or comment something that is contrary from something given by the teacher it's not something like they don't respect their teacher because every people can get 
right to have any information. So school is not place to just teach and educate but also a place for sharing knowledge." (respondent 4)

\section{Teaching and learning strategy}

When asked about their preferred teaching method or strategy which can promote high WTC, most students prefer communicative tasks where they have more chances to speak.

"...not all students are going in the classroom just to learn sentence structure, they enter classroom to know how to speak in that language, so it is also the job for ther teachers to force the students or to give them chances to practice especially for non native speakers. We want to learn English to actively participate not only with our friends but also to the native speakers." (respondent 1)

"...when the teacher is maybe teaching about writing or maybe about part of speak maybe they can make some games to make the students interest but don't just,, you know,, focus on the textbook but sometimes you know the lecture has no art and it's boring because the teachers only focus on the textbook." (respondent 5)

Five students mentioned discussion as an interesting classroom activity that will encourage the students to interact more. In discussion, students feel more relaxed talking to peers and there are more chances to practice English.

"When they use strategy like discussion, means that teachers just as facilitators so the students improve the material. In my classroom we always use student centered." (respondent 7)

Besides having to promote good WTC, pre-service teachers show eagerness to motivate their future students in many ways that are engaging. The pre-service students believe that encouraging students, compliments, and appreciation are important to foster continuous motivation to improve learning. The personal approach is also considered as important in order to avoid frustration from the students; teachers need to assist them in problem-solving.

"For example I can approach like face to face, give reward or maybe appreciation to what the students have done so they can feel more motivated and want to study more...I will always keep in touch with them, delivering more questions, if they don't understand something in English I need to provide explanation in Bahasa, and to facilitate them or make them easy to understand me, and maybe with fun learning is like songs or something like entertainment education or entertainment learning to make them interest." (respondent 6)

\section{The significance of WTC in relation to study program}

The second research question was addressed to describe pre-service teachers' perspectives about the importance of WTC in relation to their study program in English study. All ten students during the interview agreed that teachers should have good WTC. In order for the students to acquire good WTC, teachers themselves need to perform in the classroom as a good communicator. Especially related to the study program as future English teachers, the students believe that teachers are the perfect example to learn from before they actually enter the real teaching career. For instance, teachers who are good at using English, explaining, and actively looking for chances to involve students in interaction tend to gain more participation and interest. Pre-service teachers argued that teachers should have good WTC first and 
influence students to improve WTC through teachers' communication skills and teaching approaches.

"of course because he or she teach the students to encourage students how to speak, he or she have to have itself I mean WTC first before they try to encourage the students for speaking" (respondent 6)

\section{Discussion}

The findings of this study showed that pre-service teachers had high WTC in English and a relatively low level of communication anxiety. The correlation showed a negative relationship between communication anxiety to their WTC in the classroom, similar to the findings by Hasmimoto (2002) and Rastegar and Karami (2015). Many other studies in the EFL context have revealed a significant relation between English communication anxiety and its effect on WTC (McCroskey \&McCroskey, 1986; McCroskey \& Richmond,1987). This study was administered among pre-service teachers in their final year of study. Teaching preparation subjects were already taught, and participants have done small teaching practices in the classroom before. Thus, pre-service teachers are quite experienced in speaking and teaching practice. The finding also confirms MacIntyre and Gardner's (1991) study, which stated that when experience and proficiency increase, anxiety tends to decrease. The finding inferred that pre-service teachers could cope with their anxiety in the classroom resulting in an increase of WTC level.

Results revealed a fairly high level of motivational intensity in English learning, similar to the finding by Yashima (2002) and Peng and Woodrow (2010). Findings inferred that learners' motivation is manifested in both intrinsic and extrinsic interests such as acquiring a new language, learning about a new culture, being willing to communicate with native speakers, and getting more prestigious job chances in the future. This was in line with the concept of ideal L2, as explained by Munezane (2016). When learners have strong motivation and expectations on language learning, they can visualize themselves to be proficient in English and bridging their classroom experience as a manifestation for their future career. This concept of ideal L2 builds students' path to be more willing in striving for English communication in the classroom. During the interview, students' motivation seemed to come from their effort to be good teachers (respondent 3). Therefore, they put more effort in classroom interaction as a practice before facing a real teaching situation. As explained by McIntyre and Clement (1998), students who enjoy and seek satisfaction in learning and using the L2 may encourage their motivation and put more effort to learning. As Hashimoto (2012) explained, when motivation increases, anxiety level tends to decrease in a particular way, which might explain why pre-service teachers have a fairly low level of anxiety. Motivation helps learners improve self-confidence to participate in classroom tasks and improves learners' WTC (Fallah, 2013).

Throughout the interview, pre-service teachers mentioned several factors affecting their WTC such as, self-perceived communication competence, anxiety and motivation. These three variables have been found to be interrelated with each other in many research on WTC. Learners who have great anxiety are more likely to perceive themselves incapable of communication, while perceived competence tends to increase when anxiety level decreases (McCroskey and Richmond,1990; Maclntyre, Noels, and Clement,1997). Meanwhile, motivation plays an important role in building learners' trust on their own competence and help them improve perceived competence which support WTC (Yashima, 2002). Increased motivational intensity can also reduce anxiety levels (Hashimoto, 2012)

Pre-service teachers also perceived that teachers' English proficiency and teaching style can affect students' motivation to participate in the classroom. Teachers who are good at speaking English and have an interesting way of teaching are more likely to engage with the 
students. Respondent 1 during the interview pointed out that teachers who can model good English proficiency can encourage students to improve theirs as well. The same respondent also commented on being interested in teachers who are creative and engaging during learning. On the other hand, pre-service teachers can be demotivated when teaching and learning activities are boring. A study by Eddy-U (2015) and Cao (2011) also revealed similar finding where the dislike in task type was mentioned as one of a demotivating factor in the classroom. Teachers as a source of motivation and demotivation of WTC is also mentioned in Wen \& Cle'ment (2003), which included teachers' influence such as teachers' attitude, involvement, immediacy, and teaching styles. Students show a higher willingness to interact during learning when they like the teachers' attitude, involvement, and teaching styles. Several studies suggested that teachers' involvement. Attitude, and teaching style could significantly influence learners' classroom participation, engagement, and WTC (Wen \& Clément, 2003; Peng, 2007; MacIntyre et al., 2011; Zarrinabadi, 2014). In classroom learning, pre-service teachers expect teachers to encourage them in participation by actively initiating communication by utilizing various techniques such as offering questions, giving feedback, showing acceptance or rejection toward students' answers, and discussing materials with students (Cullen, 2002; Lee and Ng, 2010).

In terms of language learning beliefs, Indonesian pre-service teachers showed a moderate level of agreement on language learning beliefs items. The highest agreement on belief is shown on items related to fluency and pronunciation. Pre-service teachers mostly agreed that making mistakes in oral communication is fine and that students should be afraid to speak even if it is not correct. They also agreed that students should not hesitate to raise an opinion in the classroom even if they are not sure it is correct. On the other hand, pre-service teachers strongly disagree if speaking should be done with excellent pronunciation. They also perceive that the students who always speak up in class do not mean to be showing off and that they will not be loathed by other classmates. These beliefs are important for pre-service teachers to be internalized in their teaching behavior to positively affect their students. When students are not afraid of making mistakes in English or worrying about fluency, they would tend to put more effort into classroom communication, which leads to an improvement in WTC. This finding was in line with Horwitz (1988), where most of the participants showed agreements on items related to fluency and pronunciation. Peng (2012) explained that at a microsystem level, beliefs and learning expectations could affect learners' WTC.

Most pre-service teachers still agree on grammar rules as the most important aspect in language learning. Many of the previous research on language learning beliefs in the EFL context referred to the same finding on grammar aspects (Peacock, 1999; Peacock, 2001; Wong, 2010). Since learners come from the EFL context, it is normal that they worry about the grammar rule. Peacock (1999) inferred in his study that students who have this particular belief might focus more on learning grammar rules and disregard other types of tasks. Teachers' beliefs could be more influential than their actual knowledge because they may affect pedagogical decision-making, the acceptance and use of certain techniques, approaches, activities, and choice of classroom activities ( $\mathrm{Li}, 2013)$. Therefore, pre-service teachers are suggested to not focus only on grammar learning but also on enhancing their learning and teaching with more varieties of tasks that can improve learners' WTC. Highlighting preservice teachers' beliefs is necessary as it will reveal how these beliefs could affect their future classroom interaction strategies to facilitate learners' WTC.

The second research question attempted to investigate pre-service teachers' perception on the significance of WTC in relation to their study program. Interview data suggested that pre-service teachers were highly aware of teachers' responsibility to promote the appropriate construct of WTC among students by presenting themselves as a good communicators in classroom teaching. They perceive teachers as a role model in the classroom (respondent 1 
and 2). Pre-service teachers agreed that having good WTC is necessary for teachers because through their teaching approach and behavior, the construct of WTC is transferred to the students. If teachers desire their students to demonstrate good WTC in the classroom, then teachers first have to show good examples of having high WTC, as mentioned by respondent 6 on the significance of having good WTC for teachers. Teachers' who are competent in demonstrating oral skills are considered as one of the biggest motivations for students to achieve (Zarrinabadi, 2012). This describes the role that teachers' strategies of teaching can benefit in encouraging learners to take more active roles in classroom communication.

This study proposes several implications for teachers of language. It is suggested for teachers to emphasize increasing students' perceived competence, to reduce language anxiety, and improving classroom motivation to lead to higher WTC. Teachers can create a less threatening classroom environment to reduce anxiety and encourage students' motivation by presenting a variety of language learning tasks. As pre-service teachers proposed numbers of teachers' influence on WTC, teachers are suggested to build more interpersonal relationships with their students, improve their approach strategy and reduce the use of teachers' authority. It is important to note that beliefs can not be changed easily. Therefore, teachers are responsible for reducing students' beliefs that are detrimental to language learning, especially among pre-service teachers' as they may carry these beliefs into their future classroom teachings. Therefore, language learning should be made equal by not emphasizing only on a certain aspect of language skills.

\section{CONCLUSION}

To conclude this study, teachers and curriculum makers in the Indonesian higher education context need to enhance training in teachers' study, emphasizing the improvement of classroom interaction activities so that pre-service teachers gain higher WTC. The study is limited in the number of participants because the data collection was done during the holiday period, and students were challenging to contact. The bigger number of participants may have resulted in broader data regarding pre-service teachers' WTC and its significance related to their study program. The instruments regarding factors affecting pre-service teachers' WTC were limited to only four scales; WTC in English, communication anxiety, and motivational intensity. Therefore, future studies should include more factors that could influence WTC based on interview findings such as self-perceived communication competence, communication confidence, and classroom environment to achieve broader results.

\section{REFERENCES}

Amalia, S., Asib, A. \& Marmanto, S. (2019). Indonesian EFL Learners' Willingness to Communicate in the Instructional Context. Indonesian Journal of EFL and Linguistics, 4(2), 215-228

Ariogul, S., Unal, D. C. U. \& Onursal, I. (2009). Foreign language learners' beliefs about language learning: A study on Turkish university students. Procedia Social and Behavioral Sciences, 1, 1500-1506.

Bernat E, G. I (2005) Beliefs about language learning: current knowledge, pedagogical implications and new research directions. Online TESL-EJ 9(1).

Blunch, N., \& Ebooks Corporation. (2008). Introduction to structural equation modelling using SPSS and AMOS Niels J. Blunch. Los Angeles ; London: SAGE.

Brown, H. (2000). Principles of language learning and teaching. (4th ed.). White Plains, NY: Longman. 
Cao, Y. (2011). Investigating Situational Willingness to Communicate within Second Language Classroom from an Ecological Perspective. System: An International Journal of Educational Technology and Applied Linguistics,39(4), 468-479.

Cullen, R. (2002). Supportive Teacher Talk: The Importance of the F-Move. ELT Journal, $56(2), 117-27$.

Diab, R. L. (2006). University Students' Beliefs about Learning English and French in Lebanon. System: An International Journal of Educational Technology and Applied Linguistics,34(1), 80-96.

Dornyei, Zoltan. (2003). Attitudes, Orientations, and Motivations in Language Learning: Advances in Theory, Research, and Applications. Language Learning,53(1), 3-32.

Dornyei, Z. (2005). The psychology of the language learner : Individual differences in second language acquisition. Mahwah, N.J.: L. Erlbaum Associates.

Dornyei, Z. (2007). Research methods in applied linguistics: quantitative, qualitative, and mixed methodologies. Oxford: Oxford University Press.

Eddy-U, Mary. (2015). Motivation for Participation or Non-Participation in Group Tasks: A Dynamic Systems Model of Task-Situated Willingness to Communicate. System: An International Journal of Educational Technology and Applied Linguistics, 50, 43-55.

Fadilah, E. (2018). Willingness to Communicate from Indonesian Learners' Perspective. Journal of ELT Research. 3. 168. 10.22236/JER_Vol3Issue2pp168-185.

Fahim, A., \& Dhamotharan, M. (2016). Willingness to Communicate in English among Trainee Teachers in a Malaysian Private University. Journal of Social Sciences, 12(2),105-112.

Fallah, N. (2013). Willingness to communicate in English, communication self-confidence, motivation, shyness and teacher immediacy among Iranian English-major undergraduates: A structural equation modeling approach. Learning and Individual Differences, 2013.

Gardner, R. C. (1985). Social psychology and second language learning: The role of attitudes and motivation. London: Arnold.

Hashimoto, Y. (2002). Motivation and willingness to communicate as predictors of reported L2 use. Second Language Studies, 20(2), 29-70.

Horwitz, Elaine K., Horwitz, Michael B., \& Cope, Joann. (1986). Foreign Language Classroom Anxiety. Modern Language Journal, 70(2), 125-132.

Horwitz, E. (1988). The Beliefs about Language Learning of Beginning University Foreign Language Students. Modern Language Journal, 72(3), 283-294.

Imran, M., \& Ghani, M. (2014). A Correlational Study of Willingness to communicate and English Language Proficiency. Journal of Educational Research, 17(2), 85-99.

Kang, Su-Ja. (2005). Dynamic Emergence of Situational Willingness to Communicate in a Second Language. System: An International Journal of Educational Technology and Applied Linguistics,33(2), 277-93.

Kern, R. (1995). Students' and Teachers' Beliefs About Language Learning. Foreign Language Annals, 28(1), 71-92.

Lee, W, \& Ng, Sarah. (2010). Reducing Student Reticence through Teacher Interaction Strategy. ELT Journal, 64(3), 302-313.

Liu, M., \& Jackson, J. (2008). An Exploration of Chinese EFL Learners' Unwillingness to Communicate and Foreign Language Anxiety. Modern Language Journal,92(1), 7186.

Liu, H. J. (2012). Understanding EFL undergraduate anxiety in relation to motivation, autonomy, and language proficiency. Electronic Journal of Foreign Language Teaching, 9(1), 123-139.

MacIntyre, P. D. (1994). Variables underlying willingness to communicate: A causal 
analysis. Communication Research Reports, 11(2), 135-142.

MacIntyre, P. D., \& Charos, C. (1996). Personality, attitudes, and affect as predictors of

second language communication. Journal of Language and Social Psychology, 15(1), $3-26$.

Macintyre, P., Dörnyei, Z., Clément, R., \& Noels, K. (1998). Conceptualizing Willingness to Communicate in a L2: A Situational Model of L2 Confidence and Affiliation. Modern Language Journal, 82(4), 545-562.

Mantle-Bromley, C. (1995). Positive Attitudes and Realistic Beliefs: Links to Proficiency. Modern Language Journal,79(3), 372-386.

Mccroskey, J., \& Richmond, V. (1990). Willingness to communicate: Differing cultural perspectives. Southern Communication Journal,56(1), 72-77.

Munezane, Y. (2016). Motivation, ideal self and willingness to communicate as the predictors of observed L2 use in the classroom. EUROSLA Yearbook, 16, 85.

Nakane, I. (2006). Silence and politeness in intercultural communication in university seminars. Journal of Pragmatics,38(11), 1811-1835.

Oh, M., \& Horwitz, Elaine K. (1996). Beliefs about Language Learning and Foreign Language Anxiety: A Study of American University Students Learning Japanese, ProQuest Dissertations and Theses.

Öz, Demirezen, \& Pourfeiz. (2015). Willingness to communicate of EFL learners in Turkish context. Learning and Individual Differences,37, 269-275.

Peacock, Matthew. (1999). Beliefs about language learning and their relationship to proficiency. International Journal of Applied Linguistics, 9(2), 247-65.

Peacock, Matthew. (2001). Pre-service ESL teachers' beliefs about second language learning: A aongitudinal study. System: An International Journal of Educational Technology and Applied Linguistics,29(2), 177-95.

Peng, J.-E, \& Woodrow, L. (2010). Willingness to Communicate in English: A Model in the Chinese EFL Classroom Context. Language Learning,60(4), 834-876.

Prasetyanto, Bimo \& Wibawani, Diyah \& Wardani, Erika Novia \& Drajati, Nur. (2019). Teacher's Reinforcements Affecting Students' Willingness to Communicate (WTC): A Photovoice in EFL Classroom. Indonesian Journal of EFL and Linguistics. 4. 57. 10.21462/ijefl.v4i1.98.

Rastegar, Mina, \& Karami, Maliheh. (2015). On the relationship between foreign language classroom anxiety, willingness to communicate and scholastic success among Iranian EFL learners. Theory and Practice in Language Studies, 5(11), 2387-2394.

Wong, M. (2010). Beliefs about Language Learning: A Study of Malaysian Pre-Service Teachers. RELC Journal,41(2), 123-136.

Yang, Nae-Dong. (1999). The Relationship between EFL Learners' Beliefs and Learning Strategy Use. System: An International Journal of Educational Technology and Applied Linguistics,27(4), 515-35.

Yashima, Tomoko. (2002). Willingness to Communicate in a Second Language: The Japanese EFL Context. Modern Language Journal,86(1), 54-66.

Yousef, Reem, Jamil, Hazri, \& Razak, Nordin. (2013). Willingness to Communicate in English: A Study of Malaysian Pre-Service English Teachers. English Language Teaching,6(9), 205-216. 